\title{
INTERNALISASI SIKAP TOLERANSI MELALUI PEMBELAJARAN PAI DI SEKOLAH INDONESIA DEN HAAG
}

\author{
Riza Zahriyal Falah, Nailna Amanina, M. Ahsanul Mubarok, Moh. \\ Miftakhul Huda \\ IAIN Kudus, Kudus, Indonesia \\ rizazahriya@stainkudus.ac.id,nailna.aman@gmail.com, \\ mahsanul00@gmail.com,mifta.huda0409@gmail.com
}

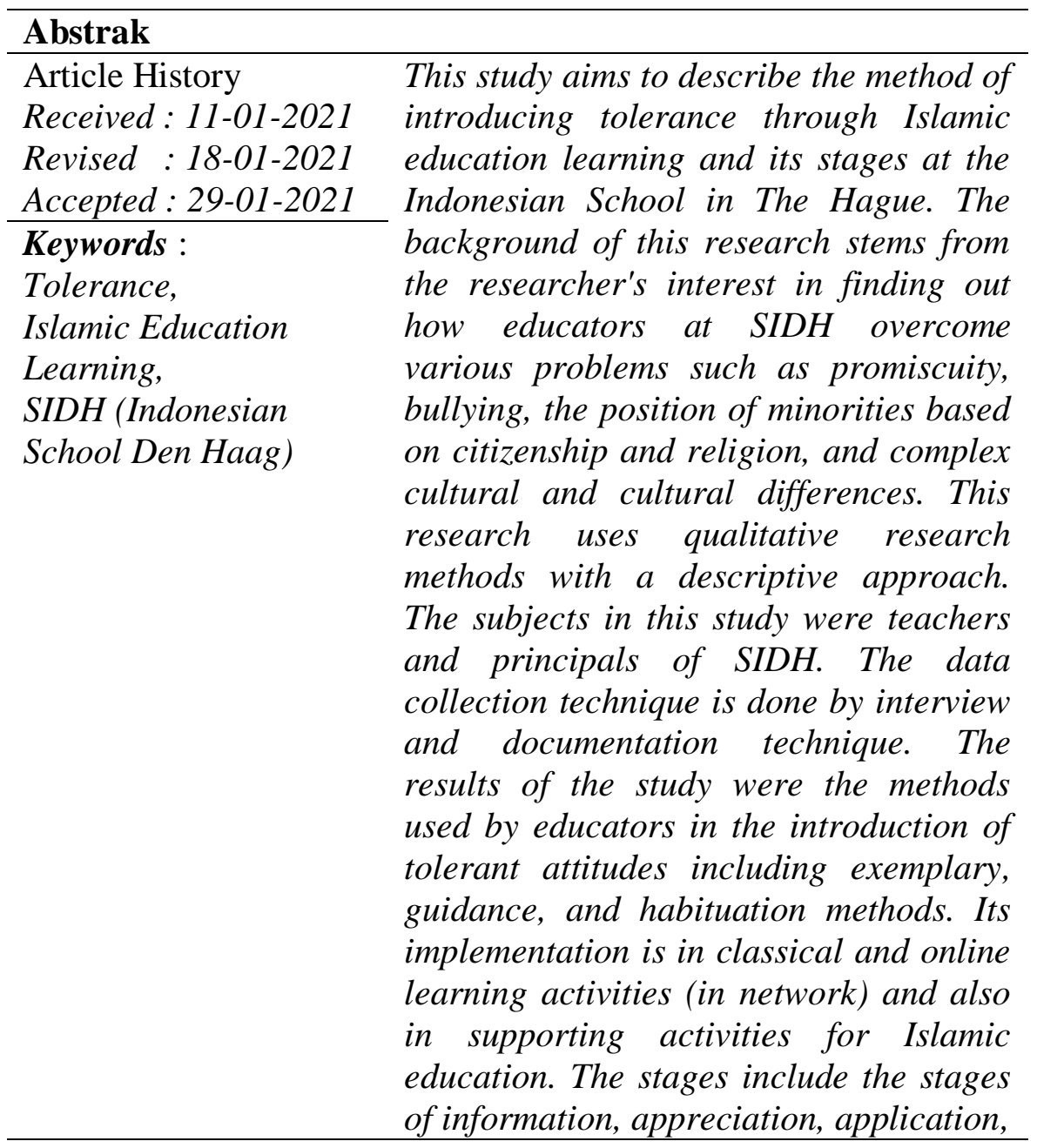




\section{Pendahuluan}

Pembelajaran Pendidikan Agama Islam merupakan salah satu amanat Undang-Undang, yaitu undang-undang nomor 20 tahun 2003 tentang Sistem Pendidikan Nasional pasal 12 ayat (1), yang menyatakan bahwa setiap peserta didik berhak untuk mendapatkan Pendidikan agama sesuai dengan keyakinannya masing-masing dan diajarkan oleh pendidik yang sesuai dengan keyakinannya. Hal ini diperkuat dengan peraturan pemerintah nomor 55 Tahun 2007 tentang Pendidikan agama dan Pendidikan keagamaan pasal 3 ayat 1 yang menyebutkan bahwa Lembaga Pendidikan pada semua jalur, jenjang, dan jenis Pendidikan wajib untuk melaksanakan Pendidikan agama. Melihat landasan yuridis tersebut, pembelajaran pendidikan agama Islam dalam Lembaga Pendidikan menjadi keniscayaan dan harus dilakukan oleh setiap Lembaga Pendidikan. Implementasi dari pasal ini adalah munculnya pembelajaran Pendidikan Agama Islam yang diwujudkan tidak hanya dalam bentuk mata pelajaran, tapi juga kegiatan penunjang lain yang mengarah pada praktik keagamaan seperti sholat berjama'ah, berdo'a, dan lain sebagainya, tergantung kebijakan masing-masing Lembaga Pendidikan.

Arah dan tujuan pembelajaran Pendidikan agama Islam antara masing-masing Lembaga Pendidikan bisa berbeda tergantung pada visi dan misi serta tujuannya. Keragaman arah dan tujuan itu salah satunya menyesuaikan dengan kondisi sosio kultural dimana Lembaga tersebut berada. Namun secara garis besar, proses pembelaran Pendidikan Agama Islam mempunyai tujuan menyiapkan peserta didik untuk berakhlak mulia yang berdasarkan pada sumber ajaran Islam, yaitu al-Qur'an dan Hadist (Depdiknas, 2003: 7). Pelaksanaannya tidak hanya diwujudkan dalam bentuk pembelajaran kelas, tapi juga dibarengi dengan latihan, bimbingan, praktik pengalaman yang dibarengi dengan penyadaran menghormati umat agama lain untuk menciptakan suasana kerukunan antar umat beragama dalam bingkai persatuan bangsa sebagaimana amanat Undang-Undang Dasar 1945 dan Pancasila.

Fakta menunjukkan bahwa bangsa Indonesia memiliki keanekaragaman suku, agama, ras dan budaya. Menyikapi keanekaragaman ini, dalam rangka mempertahankan persatuan dan kesatuan bangsa, diperlukan adanya sikap toleransi satu sama lain antar rakyat Indonesia. Sikap toleransi merupakan salah satu kunci untuk tetap hidup nyaman berdampingan, meskipun berbeda budaya 
dan keyakinan. Memberikan pemahaman toleransi merupakan usaha yang tidak dapat dijalankan sendiri, atau dalam bentuk satu pengalaman tanpa ada pengalaman lain yang mendukung. Pembelajaran Pendidikan Agama Islam merupakan salah satu bentuk usaha secara sadar yang dilakukan oleh Lembaga Pendidikan untuk menanamkan sikap toleransi kepada peserta didik. Toleransi merupakan bagian dari akhlak yang baik yang mana merupakan salah satu substansi dari ajaran Islam, yaitu bersikap baik kepada orang lain, baik yang berbeda secara keyakinan, suku, ras, golongan, dan perbedaan-perbedaan yang lain. Toleransi dan berbagai macam akhlak yang baik yang lain, yang dihayati dan diamalkan umat Islam, akan mencerminkan karakter utama Islam, yaitu umat yang rahmatan lil 'alamin. Pembelajaran Pendidikan agama Islam pada tataran ideal harusnya mampu membangun kesadaran multikulturalisme, yang pada akhirnya akan memunculkan sikap toleransi kepada umat agama lain. (Hamid, 2016)

Salah satu komponen penting yang dapat menghidupkan kesadaran multicultural kepada peserta didik adalah pendidik. Tugas utama guru tidak hanya memberikan kemampuan kognitif kepada peserta didik, tetapi juga nilai-nilai yang menjadi tumpuan peserta didik ketika bergaul dengan orang lain. Melihat potensi kemajemukan yang bakal dihadapi peserta didik, secara ideal pendidik harus mampu memberikan kesadaran kepada peserta didik untuk bersikap toleran terhadap kemajemukan-kemajemukan yang akan dihadapi. Maka dari itu proses pembelajaran di sekolah sudah seharusnya memberikan pemahaman nilai toleransi kepada peserta didik. Karena pada idealnya, dalam masalah sikap toleransi ini, pendidik mempunyai peran penting, pertama pendidik harus bisa bersikap demokratis, sehingga memberi kesadaran kepada peserta didik bahwa menghormati keputusan orang lain itu harus dilakukan asalkan tidak melanggar norma-norma tertentu. Kedua pendidik harus mempunyai kepekaan dan kepedulian terhadap kejadian-kejadian tertentu yang melanggar nilai toleransi. Ketiga pendidik harus bisa memberikan pemahaman bahwa substansi agama adalah kedamaian dan kesejahteraan, bukan sikap eksklusif kepada umat agama lain. Keempat pendidik harus bisa memberikan kesadaran pentingnya berdialog dan bermusyawarah ketika berhadapan dengan permasalahan yang menyangkut keragaman budaya, etnis, agama, dan golongan. (Muliadi, 2012) Pada tata ideal ini, pendidik harus bisa 
menanamkan tujuan utama dari pembelajan PAI selain bertaqwa kepada Allah, yaitu mempunyai sikap toleransi yang merupakan bagian dari akhlak mulia. (Depdiknas, 2003)

Sekolah Indonesia Den Haag (disingkat SIDH) merupakan Lembaga sekolah yang dikelola dan berada dibawah naungan Kedutaan Besar Republik Indonesia (KBRI) Belanda. Sekolah ini memiliki tiga tingkatan Pendidikan, yaitu sekolah dasar (SD), sekolah menengah pertama (SMP), dan sekolah menengah atas (SMA). Ketiganya berada dalam satu lingkungan sekolah yang sebagian besar peserta didiknya adalah putra-putri warga negara Indonesia (WNI) yang sedang berdomisili di Belanda dan sekitarnya. SIDH didirikan pada tanggal 15 Juni 1965 dan berlokasi di Rijksstraatweg 679, 2245 $\mathrm{CB}$, Wassenaar, Belanda. Pendirian SIDH dilakukan melalui panitia Sekolah dan kebudayaan Indonesia (BASUKI). Pada awalnya, nama Sekolah ini adalah Sekolah Indonesia Nederland (SIN), kemudian berdasarkan keputusan Menteri Pendidikan dan Kebudayaan tanggal 15 Agustus 1995 berubah menjadi Sekolah Kedutaan Republik Indonesia di Wassenaar. Beberapa lama kemudian nama Sekolah ini dikembalikan menjadi Sekolah Indonesia Nederland, dan sejak Agustus 2015 namanya dirubah menjadi Sekolah Indonesia Den Haag.

Sekolah Indonesia Den Haag didanai secara penuh oleh Pemerintah Indonesia dan berstatus sebagai Sekolah negeri. SIDH juga sudah menyelenggarakan Ujian Akhir Nasional yang mempunyai kualifikasi yang sama dengan Sekolah-sekolah negeri lain di Indonesia. Pada tanggal 9 September 2011, SIDH diakui sebagai Sekolah asing oleh Ministry of Education, Culture, and Science Pemerintah Belanda. Pada tahun 2016, SIDH melakukan reakreditasi dan mendapatkan nilai akreditasi "A" untuk semua jenjang Pendidikan yang dilakukan oleh Badan Akreditasi Nasional Sekolah dan Madrasah. Nilai ini lebih baik dibanding nilai akreditasi sebelumnya yang dilakukan pada tahun 2011. (http://www.sekolahindonesia.nl/profil-sekolah/)

Penelitian ini merupakan tindak lanjut dari kegiatan Kuliah Kerja Lapangan program studi Pendidikan Agama Islam IAIN Kudus yang dilaksanakan secara virtual bekerjasama dengan sekolah Indonesia Den Haag. Selama kegiatan Kuliah Kerja lapangan, peneliti menemukan beberapa permasalahan yang dihadapi pendidik di sekolah Indonesia Den Haag seperti pergaulan bebas, bullying, posisi 
minoritas secara kewarganegaraan dan agama, dan perbedan kultur serta budaya yang kompleks yang kemudian mengharuskan pendidik SIDH untuk menemukan solusi atas permasalahan-permasalahan tersebut. Dengan latar belakang kenegaraan (karena posisinya berada di negara lain), dan juga latar belakang peserta didik yang berbeda (karena berasal dari berbagai wilayah di Indonesia), Pembelajaran PAI secara ideal harusnya bisa menjadi salah satu solusi dalam menanamkan sikap toleransi kepada peserta didik SIDH, sehingga tidak terkungkung dalam pandangan sempit sektarian yang berasal dari perbedaan latar belakang tersebut. Proses pembelajaran pendidikan agama Islam di SIDH secara ideal seharusnya dapat mewujudkan peserta didik yang mempunyai kompetensi beriman serta bertaqwa kepada Allah swt, dan berakhlak mulia yang merupakan cerminan dari sifat-sifat Rasulullah saw.

Dari kerangka berpikir di atas dan masalah yang peneliti temukan tersebut, peneliti tertarik untuk meneliti bagaimana internalisasi sikap toleransi melalui pembelajaran PAI di sekolah Indonesia Den Haag. Tujuan penelitian ini adalah untuk mendapatkan formulasi internalisasi skap toleransi yang dilakukan SIDH melalui pembelajaran Pendidikan agama Islam, sehingga bisa menjadi dasar dan pedoman bagi Lembaga Pendidikan lain, baik yang posisinya sama seperti SIDH maupun yang berbeda. Subyek penelitian dalam penelitian ini bisa dibilang masih baru atau belum ada penelitian sebelumnya yang meneliti subyek penelitian ini, walaupun secara tema, sudah ada beberapa penelitian yang dilakukan sebelumnya sebagaimana yang peneliti kutip di atas. Sehingga penelitian ini berusaha mengeksplorasi tentang internalisasi sikap toleransi kepada peserta didik yang subyeknya berbeda dengan penelitian-penelitian sebelumnya.

\section{Kajian Teori Internalisasi}

Kata internalisasi dalam Kamus Besar Bahasa Indonesia mempunyai pengertian sebagai penghayatan terhadap suatu ajaran, doktrin ataupun nilai sehingga menjadi sebuah keyakinan dan kesadaran akan sebuah nilai tersebut dan mewujudkan perilaku atau sikap yang sesuai dengan nilai atau ajaran tersebut (KBBI Daring Kemendikbud: 2020). Internalisasi juga dapat dikatakan sebagai wujud cara atau tindakan dalam hal menghayati dan menjelajahi lebih dalam sebuah nilai dengan maksud agar dapat tumbuh dan tertanam 
dalam kepribadian seseorang yang dilaukan melalui pemberian suri tauladan, penerapan kebiasaan, penegakan hukum dan aturan serta pemberin motivasi. Istilah internalisasi menurut Chalari, menjelaskan bahwa internalisasi merupakan sebuah tahapan yang berbentuk proses dari kemampuan manusia yang normal dalam hal menerima, menjalankan proses, dan mentransformasikan setiap kejadian ke dalam perkataan maupun perbuatan. Sedangkan menurut Muhaimin, beliau menjelaskan lebih spesifik lagi mengenai internalisasi nilai. Menurut beliau internalisasi nilai dapat diartikan sebagai kegiatan menanamkan dan menyatukan nilai-nilai Islam ke dalam diri seseorang (peserta didik), dengan tujuan agar menjadi sebuah karakter atau watak dari seseorang yang berbasis Islami (Ardianto, 2020: 56) Sedangkan jika kata internalisasi disandingkan dengan nilai-nilai PAI, maka dapat diartikan sebagai cara atau tindakan serta upaya memasukkan nilai-nilai ajaran agama Islam melalui proses pemahaman keagamaan agar tumbuh dalam jiwa dan raga setiap orang dan menjadi biasa dilakukan dalam kehidupan sehari-hari (Muhammad Munif, 2017: 3). Sehingga inti dari bentuk internalisasi yaitu proses menanamkan sebuah nilai dengan dilakukan dalam sebuah pembinaan untuk mewujudkan tumbuh dan berkembangnya nilai tersebut dalam diri seseorang secara utuh dan mendalam.

\section{Toleransi}

Toleransi sendiri dapat diartikan dengan sikap tenggang rasa (menghargai, dapat membolehkan ataupun membiarkan) pendapat, keyakinan, kelakuan, pandangan, kebiasaan dan lain sebagainya dari sesorang yang berbeda atau tidak sejalan dengan diri sendiri. Toleransi juga dapat diartikan berbanding lurur dengan ajaran fundamental, yang meliputi rahmah (kasih sayang), hikmah (kebijaksanaan), al-maslahah al-ammah (kemaslahatan bersama) dan keadilan. (Nedia Marpita Sari, 2019: 13)

Sebagai pusat pendidikan toleransi, sekolah diharapkan dapat mengajak siswa dalam pandangan yang positif, yaitu menanamkan sebuah sikap toleransi di atas perbedaan satu sama lain serta terhadap keberadaan kaum minoritas. Keberadaan toleransi adalah sebagai nilai dasar yang saat ini sangat dibutuhkan dalam membangun dan memperkokoh kohesi sosial masyarakat yang multikultur seperti Indonesia. Penanaman toleransi ini banyak memerlukan keterlibatan berbagai pihak, tidak terkecuali pada lembaga-lembaga pendidikan yang ada baik formal maupun informal. Keterlibatan lembaga 
pendidikan dinilai sangat besar pengaruhnya dalam membentuk pola pikir generasi pada masa yang akan datang. Sekolah merupakan tempat dimana peserta didik menerima nilai yang baik maupun nilai yang buruk, penerimaan ini akan memberikan bekas dalam kehidupan yang nyata. (Muhammad Usman dan Anton Widyanto, 2019: 38)

Sebagaimana tujuan dari pendidikan Islam adalah menginformasikan, mentransformasikan serta menginternalisasikan tentang nilai-nilai Islam. Dengan demikian maka pendidikan Islam dapat mengajarkan moral positif yang berakar pada nilai-nilai kajian Islami, sebagai pendorong moral reasioning atau penalaran akhlak yang sangat dibtuhkan untuk menentukan pilihan dan keputusan tentang masalah-masalah yang baru muncul dalam proses pembangunan ini. Untuk itu maka, pendidikan Islam harus mampu menyajikan learning experiences atau pengalaman belajar yang dapat merangsang kesadaran dan komitmennya mengenai masalah sosial dan etika dalam msyarakat, yang memungkinkan dapat ikut mengatasi dilema pada masa sekarang. (Afidatul Umroh, 2015: 3)

Selanjutnya, pada penelitian Muhammad Munif sebelumnya menyebutkan bahwa strategi internalisasi dapat dilakukan dengan berbagai tahapan dan proses satu sama lain. Pada artikel tersebut secara umum menjelaskan cakupan subjek penelitian yaitu pada siswa PAI di sekolah saja dan kurang dispesifikasikan lebih lanjut, sehingga berdasarkan berbagai permasalahan tersebut, pembahasan dalam artikel ini memberi batasan mengenai subjek yang diambil yaitu pada guru (tutor) dan kepala sekolah di Sekolah Indonesia Den Haag (SIDH). Tahapan-tahapan yang disebutkan Muhammad Munif tersebut diantaranya yaitu Tahapan transformasi nilai. Pada tahapan pertama ini atau disebut dengan tahapan tranformasi nilai. Kata tranformasi sendiri merupakan perubahan tampilan fisik berupa bentuk, sifat, fungsi dan lain sebgainya. Transformasi ini juga dapat ditandai dengan adanya komunikasi verbal yang membahas tentang pemilihan dan pemilahan diantara nilai yang baik dengan nilai yang kurang baik, sehingga peserta didik dapat mengklasifikasikan antara nilai-nilai yang baik dan yang tidak baik. Tahapan kedua yaitu transaksi nilai yaitu tahap transaksi nilai, yang mana dari kata transaksi sendiri memiliki artian adanya hubungan timbal balik yang dilakukan oleh minimal dua orang. Dalam kasus ini berarti orang yang terlibat yaitu antara pendidik dan peserta didik terdapat hubungan timbal balik yang berupa sebuah komunikasi dua arah atau 
interaksi yang bersifat timbal balik. Sebagai contoh yaitu pada seorang pendidik melakukan penerapan atau amalan nyata dari tiap nilai-nilai PAI dalam kehidupannya sehari-hari, sedangkan oleh peserta didik meniru dan mengikuti bentuk amalan baik yang telah dicontohkan seorang pendidik dalam kehidupan nyata. Inti dari tahapan ini yaitu adanya tampilan sosok fisik dari seorang peserta didik. Dan tahapan terakhir yaitu transinternalisasi yaitu tahap transinternalisasi yang merupakan sebuah perwujudan lanjutan dari tahapan transaksi, yaitu perwujudan sikap yang tidak hanya mengenai sosok fisiknya saja dalam menerapkan nilai-nilai Islam, melainkan juga mewujudkan sikap mental dari nilai-nilai Islam tersebut sehingga akan membentuk kepribadian yang Islami dan mewujudkan sebuah karakter yang Islami pula.

Selain itu, menurut Thomas Lickona menyebutkan berapa tahapan internalisasi yang kaitannya juga apat dijadikan rujukan sebagai perwujudan pembangunan karakter, antara lain yaitu (Firly Maulana Sani, 2016: 25). Moral knowing, tahapan ini menjelaskan tentang pemberian pengetahuan mengenai moral atau nilai tersebut, dalam artian sebagai tahap mengetahui moral dan nilai-nilai Islam, karena pada langkah awal untuk menerapkan nilai Islami tersebut yaitu mengetahui terlebih dahulu Moral feeling, tahapan ini menjelaskan tentang bahasan perasaan mengenai moral atau nilai tersebut, dalam artian sebagai tahap merasakan norma tersebut, yang mana pada tahapan setelah mengetahui dapat merasakan dari moral tersebut. Moral action, tahapan ini menjelaskan tentang pelaksanaannya atau yang disebut penerapan dari berbagai moral yang telah melewati tahapan sebelumnya, sehingga proses terakhir yaitu dapat menerapkannya dalam kehidupan nyata sehari-hari.

\section{Metode Penelitian}

Penelitian ini menggunakan metode penelitian kualitatif dengan pendekatan deskriptif. Karena deskriptif, maka penelitian ini menjelaskan secara komprehensif temuan-temuan penelitian sehingga bisa dipahami pembaca dengan baik. Teknik pengumpulan data yang dilakukan adalah menggunakan Teknik wawancara dan dokumentasi. Karena jauhnya jarak subyek penelitian, maka peneliti tidak begitu begitu maksimal dalam menggunakan Teknik observasi. Wawancara yang peneliti gunakan adalah wawancara tidak terstruktur yang peneliti lakukan dengan melakukan wawancara kepada pendidik di 
SIDH yaitu Dessy Nataliani dan Ponco Handayawati, ditambah wawancara dengan kepala Sekolah SIDH, Gunaryadi. Adapun Teknik dokumentasi peneliti lakukan selama kegiatan Kuliah Kerja Lapangan (KKL) yang direkam menggunakan aplikasi Zoom meeting.

Waktu penelitian ini adalah selama bulan Agustus tahun 2020. Adapun uji keabsahan data yang peneliti lakukan penggunakan Teknik perpanjangan pengamatan dan triangulasi yang meliputi triangulasi sumber, waktu, dan Teknik. Teknik analisis data yang peneliti gunakan meliputi pengumpualan data, reduksi data, penyimpulan data dan verifikasi data.

\section{Pembahasan}

\section{Metode Internalisasi Sikap Toleransi Melalui Pembelajaran PAI di Sekolah Indonesia Den Haag}

Secara teoritis, kegiatan internalisasi karakter tidak mempunyai struktur yang baku dan transparan sebagaimana pembelajaran yang bersifat kognitif. Sehingga Lembaga Pendidikan melalui pendidik, diwajibkan untuk memasukkan nilai-nilai karakter yang harus dipahami peserta didik ke dalam kegiatan pembelajaran, termasuk pembelajaran Pendidikan agama Islam. Walaupun secara teoritis, materi Pendidikan agama Islam juga berisi tentang pembelajaran akhlak, namun akan sangat bias kalua kemudian materi tersebut hanya dipahami secara kognitif tanpa ada proses internalisasi. Suatu pengetahuan akan jadi sesuatu yang tidak berguna ketika hanya sekedar diketahui tanpa diimplementasikan. Maka dari itu diperlukan metode yang tepat untuk mengintenalisasikan sikap toleransi kepada peserta didik, sehingga pengetahuan tentang toleransi tidak hanya "diketahui" oleh peserta didik saja, namun juga diimplementasikan dalam kehidupan sehari-hari. Konsep inilah yang kemudian disebut Thomas Lickona sebagai doing the good, sebagai lanjutan dari knowing the good, dan loving the good. Metode yang digunakan SIDH dalam melakukan internalisasi sikap toleransi pada pembelajaran PAI dapat dilalukan melalui beberapa metode berikut:

\section{Keteladan}

Konsep keteladanan merupakan salah satu konsep yang dijelaskan Allah swt dalam al-Qur'an, khusus dalam surat al-Ahzab ayat 21 yang artinya "Sesungguhnya telah ada pada (diri) Rasulullah itu suri teladan yang baik bagimu (yaitu) bagi orang yang mengharap 
(rahmat) Allah dan (kedatangan) hari kiamat dan Dia banyak menyebut Allah". Oleh karena itu dapat dikatakan bahwa keteladanan merupakan pendekatan dalam pendidikan karakter yang ampuh. Dalam lingkungan keluarga misalnya, anak akan suka meniru gaya hidup orang tua. Orang tua yang rajin beribadah akan membuahkan anak yang rajin beribadah pula. Disamping itu, tanpa keteladanan, apa yang diajarkan pada anak hanya akan menjadi teori belaka. Anak seperti gudang ilmu berjalan namun tidak merealisasikan dalam kehidupan. Lebih utama lagi, metode keteladanan ini dapat dilakukan setiap saat dan setiap waktu.

Keteladanan dalam pendidikan adalah metode influentif yang paling meyakinkan keberhasilannya dalam mempersiapkan dan membentuk anak di dalam moral, spiritual dan sosial. (Ulwan, 1993: 2) Hal ini adalah karena pendidik adalah contoh terbaik dalam pandangan peserta didik, yang akan ditiru dalam tindak tanduknya dan tata santunnya, disadari atau tidak, bahkan tercetak dalam jiwa dan perasaan peserta didik suatu gambaran pendidik tersebut, baik ucapan atau perbuatan, material maupun spiritual, diketahui maupun tidak diketahui.

Dalam internalisasi sikap toleransi, permodelan atau pemberian teladan merupakan metode yang tepat digunakan. Hal ini karena mengingat bahwa sikap atau karakter merupakan perilaku (behaviour), bukan pengetahuan sehingga sehingga dalam internalisasinya pada peserta didik lebih tepat dengan diteladankan, bukan diajarkan.

Dalam mendidik karakter, sangat dibutuhkan sosok yang dijadikan sebagai model. Model dapat ditemukan oleh peserta didik dari lingkungan sekitarnya. Semakin dekat model pada peserta didik, maka semakin mudah dan efektiflah pendidikan karakter tersebut. peserta didik butuh cintoh nyata, bukan hanya contoh yang ada dalam buku. Hal ini senada dengan ungkapan Berk yang dikutip oleh Siti Masganti, (Masganti, 2010) perilaku moral diperoleh dengan cara yang sama dengan respons-respons lainnya, yaitu melalui modeling dan penguatan. Lewat pembelajaran modeling (keteladanan) akan terjadi internalisasi perilaku moral, prososial dan aturan-aturan lainnya untuk tindakan yang baik. Demikian juga menurut social learning theory yang dikutip oleh Nurchailli, (2010) perlaku manusia diperoleh melalui cara pengamatan model, mengamati orang lain, 
membentuk ide dan perilaku-perilaku baru, dan akhirnya digunakan sebagai arahan untuk berinteraksi.

Peserta didik biasanya cenderung melakukan sesuatu dengan meneladani pendidiknya. Hal ini dapat dipahami, bahwa secara psikologis, peserta didik memang suka meniru apa yang dilihat, baik itu benar maupun salah, seperti ungkapan Ibnu Sina, adanya pengaruh "mengikuti atau meniru" atau contoh teladan yang baik dalam proses pendidikan dikalangan anak usia dini terhadap kehidupanya, karena secara thabi'iyyah (kebiasaan atau ciri khas) peserta didik memiliki kecenderungan untuk mengikuti dan meniru sesuatu yang disaksikan dan dirasakan serta yang didengar. Peserta didik lebih belajar dari apa yang dilihat. Verba movent exempla trahunt. Kata-kata itu memang dapat menggerakkan orang, namun teladan lebih dapat menggerakkan hati. (Koesoema, 2010: 214) Untuk itu interalisasi sikap sesungguhnya lebih merupakan tuntutan terutama bagi kalangan pendidik sendiri. Sebab, pengetahuan yang baik tentang nilai akan menjadi tidak kredibel ketika gagasan teoritis normatif nan apik itu tidak pernah ditemui oleh peserta didik dalam praksis kehidupan mereka baik dirumah maupun disekolah. (Koesoema, 2010: 214)

Keteladanan juga memiliki kontribusi besar bagi pendidikan di sekolah. Keteladanan pendidik dalam berbagai aktivitasnya akan menjadi cermin bagi siswanya. Oleh karena itu, sosok pendidik yang bisa diteladani siswa merupakan hal yang penting. Pendidik yang suka membaca, meneliti, ramah, disiplin, berakhlak misalnya akan menjadi teladan yang baik bagi siswa, Demikian juga sebaliknya. Keteladanan yang dilakukan juga haruslah keteladanan yang multidimensi, yakni keteladanan dalam berbagai aspek kehidupan. Bukan bersifat parsial.

Melihat dari pentingnya peran orang tua dan pendidik maka Sekolah Indonesia Den Haag (SIDH) memberikan bentuk pembelajaran pendidikan agama Islam yang dapat terjadi baik di rumah dan di sekolah. Bentuk pembelajaran tersebut dikenal dengan "Rumah Belajar" sebagai wadah komunikasi dan interaksi pembelajaran yang dilaksanakan baik di rumah maupun di sekolah. Kegiatan pembelajaran ini mencakup semua mata pelajaran dengan sistem klasikal dan daring (dalam jaringan). Pendidik sebagai penentu materi dan capaian pembelajaran, memberikan petunjuk kepada orang tua dirumah agar pelaksanaan pembelajaran tidak hanya terfokus pada pendidik di Sekolah, tapi juga melibatkan orang tua dirumah. 
Dalam pembelajaran Pendidikan agama Islam, pendidik memberikan prinsip-prinsip keteladanan yang harus dilakukan orang tua dirumah. Prinsip tersebut antara lain prinsip berkata, bersikap, dan mengambil keputusan, yang mana juga dilakukan pendidik ketika pembelajaran di Sekolah. Prinsip dalam berkata dilakukan dengan mempertimbangkan budaya sopan santun, lemah lembut, persuasif, kasih sayang, dan menggunakan nada bicara yang menyenangkan. Prinsip bersikap ditunjukkan dengan interaksi yang demokratis, perhatian terhadap perkembangan peserta didik, dan motivasi. Sedangkan prinsip pengambilan keputusan yang dilakukan adalah dengan selalu berdiskusi dan musyawarah dengan peserta didik, jadi memberikan keteladanan kepada peserta didik bahwa ada suara lain yang harus dipertimbangkan ketika akan mengambil keputusan tertentu dan mempunyai posisi yang sama.

Selain pada kegiatan pembelajaran, internalisasi sikap toleransi dengan cara teladan juga dilakukan di luar kegiatan pembelajaran di SIDH. Keteladanan ini ditunjukkan dalam kegiatan pendukung pembelajaran Pendidikan Agama Islam seperti kegiatan berdo'a ketika akan memulai pembelajaran sesuai agama masingmasing, shalat berjama'ah dan kegiatan ibadah agama lain, dan kegiatan ramdhan camp yang dikhususkan bagi peserta didik muslim. Prinsip-prinsip keteladanan sebagaimana disebutkan sebelumnya di atas dilakukan dalam kegiatan-kegiatan penunjang ini. Zakiah Dadjat menyimpulkan metode teladan merupakan metode yang tepat dalam menginternalisasikan sikap/karakter kepada peserta didik, karena dalam menyikapi keberagaman Indonesia, seorang warga negara Indonesia harus dapat memberi teladan toleransi untuk dapat mengajak seseorang mengikutinya. (U. Abdullah Mumin, 2018: 23)

\section{Bimbingan}

Pendidikan merupakan usaha secara sadar dan terencana yang dilakukan oleh orang dewasa untuk menciptakan proses belajar dan pembelajaran peserta didik dalam mencapai tujuan tertentu. Usaha secara sadar dan terencana ini dalam proses pembelajaran salah satunya adalah dengan proses bimbingan yang dilakukan pendidik sebagai orang dewasa kepada peserta didik. Dalam internalisasi sikap toleransi melalui pembelajaran Pendidikan agama Islam, pendidik di SIDH tidak hanya menyampaikan materi Pendidikan agama Islam khususnya toleransi secara verbal, namun juga membimbing secara aktif peserta didik untuk melaksanakan sikap tersebut dalam 
kehidupan di Sekolah. Bentuk bimbingan ini dilakukan dalam kegiatan-kegiatan penunjang pembelajaran Pendidikan agama Islam seperti Shalat berjama'ah, berdo'a sebelum belajar, dan Ramadhan camp.

Bimbingan yang utama dilakukan oleh guru kelas yang bertanggung jawab terhadap pelaksanaan kegiatan penunjang pembelajaran Pendidikan agama Islam, dibantu dengan staff dan guru lain. Selain bimbingan dalam bentuk pelaksanaan kegiatan penunjang pembelajaran Pendidikan Agama Islam, peserta didik juga dibimbing untuk mengenali dan membiasakan diri bersikap yang baik kepada warga negara asing, dikarenakan WNI disana merupakan minoritas. Bimbingan ini sebagai bentuk pemberian pemahaman bahwa perlindungan kepada minoritas itu penting untuk dilakukan. Pross bimbingan ini dilakukan dalam kegiatan karyawisata, atau study Lapangan yang dilakukan secara rutin oleh SIDH. Legalitas SIDH sebagai Sekolah asing dan diakui oleh pemerintah Belanda, ikut mempermudah SIDH ketika akan melaksanakan kegiatan di luar Sekolah.

Bimbingan yang dilakukan di Sekolah Indonesia Den Haag (SIDH) sesuai dengan merupakan implementasi metode nasihat sebagaimana konsep Abdullah Nasih Ulwan yang dikutip oleh Nur Ainiyah yang menyebutkan tentang konsep pendidikan inluentif pada pendidikan akhlak seorang anak yang meliputi pendidikan melalui keteladanan, pendidikan melalui adat kebiasaan, pendidikan melalui nasihat, pendidikan melalui perhatian dan hukuman. (Nur Ainiyah, 2013: 34) Metode internalisasi sikap toleransi dengan bimbingan sudah sesuai dengan konsep pendidikan melalui nasihat, karena dalam pemberian nasihat di dalamnya juga disertai dengan bimbingan terkait sikap toleransi terhadap orang lain.

\section{Pembiasaan}

Pembiasaan merupakan proses penanaman kebiasaan. Kebiasaan (Habit) adalah cara-cara bertindak yang persistent, uniform dan hampir-hampir otomatis (hampir-hampir tidak disadari oleh pelakunya). (Ali, 1999: 84) Inti pembiasaan adalah pengulangan. Ali al-Jumbulati mengatakan, psikologi modern memandang bahwa pengulangan itu merupakan salah satu metode belajar yang baik, karena dapat memperbaiki pengetahuan pada tahap permualaannya yang sesuai atau benar dengan teori kemampuan menangkap 
pengertian manusia terhadap obyek pengamatan. (at-Tawanisi dan alJumbulati, 1994: 200)

Pembiasaan atau habituation merupakan proses pembentukan sikap dan perilaku yang relatif menetap dan bersifat otomatis melalui proses pembelajaran yang berulang-ulang. Sikap atau perilaku yang menjadi kebiasaan mempunyai ciri seperti perilaku tersebut relatif menetap, umumnya tidak memerlukan fungsi berpikir yang cukup tinggi, misalnya untuk dapat mengucapkan salam cukup fungsi berpikir berupa mengingat atau meniru saja, bukan sebagai hasil dari proses kematangan, tetapi sebagai akibat atau hasil pengalaman atau belajar, dan tampil secara berulang-ulang sebagai respons terhadap stimulus yang sama. Terdapat sedikit perbedaan antara proses keteladanan dan proses pembiasaan. Akan tetapi kedua hal tersebut saling menunjang. Keteladanan merupakan konotasi kata yang positif, sehingga hal-hal yang mengikuti adalah perilaku, sikap, maupun perbuatan yang secara normatif baik dan benar. Dalam keteladanan terdapat unsur mengajak secara tidak langsung, sehingga terkadang kurang efektif tanpa ada ajakan secara langsung yang berupa pembiasaan. Begitu pula dengan pembiasaan yang secara langsung mengarahkan pada suatu perilaku, sikap maupun perbuatan yang diharapkan, kurang dapat berhasil dengan baik tanpa adanya keteladanan.

Dengan metode pembiasaan, akan terbentuk karakter walaupun membutuhkan waktu relatif lama dan terus menerus. Hal ini sesuai dengan kalimat yang berbunyi "orang bisa karena biasa". Kalimat lain juga menyatakan "pertama-tama kita membentuk kebiasaan, kemudian kebiasaan membentuk kita". Pembiasaan diarahkan pada upaya pembudayaan pada aktivitas tertentu sehingga menjadi aktivitas yang terpola atau tersistem.

Internalisasi sikap toleransi di SIDH (Sekolah Indonesia Den Haag) juga dilakukan dengan cara membiasakan peserta didik untuk saling menghormati satu sama lain, serta memberikan bimbingan ketika ada peserta didik yang melanggar norma peraturan Sekolah. Seperti terlihat dalam proses pelaksanaan sholat berjama'ah, peserta didik dibiasakan untuk mengikuti sholat berjama'ah dengan bimbinga langsung dari guru. Pembiasaan megikuti sholat berjama'ah ini selain membiasakan peserta didik terbiasa untuk melaksanakan sholat berjama'ah, juga mempunyai anggapan bahwa semua manusia menempati posisi yang sama di mata Tuhan. Pandangan sama ini 
mempunyai tujuan agar tidak ada sikap superior atau inferior yang berujung pada praktik intoleransi dalam kehidupan sehari-hari peserta didik. Dalam kegiatan ini juga diperlihatkan proses menghormati umat agama lain yang tidak ikut sholat untuk berdoa sesuai keyakinannya masing-masing. Proses pembiasaan seperti ini akan melahirkan sikap menghargai satu sama lain sehingga mampu menanamkan sikap toleransi dalam diri peserta didik. (Nurliah, 2019: 78)

Tahapan Internalisasi Sikap Toleransi Melalui Pembelajaran PAI di Sekolah Indonesia Den Haag

Selain metode yang telah tepat untuk digunakan dalam proses internalisasi sikap toleransi tersebut, selanjutnya yaitu terkait tahapan internalisasi sikap toleransi pada pembelajaran PAI di Sekolah Indonesia Den Haag. Tahapan internalisasi yang terjadi di SIDH dapat diklasifikasikan menjadi tiga tahapan yaitu tahapan informasi (ranah afektif), tahapan penghayatan (ranah kognitif) dan tahapan aplikasi (ranah psikomotorik). (Ahmad Budiman, 2020: 105)

\section{a. Tahapan Informasi (ranah afektif)}

Pada tahapan informasi ini, guru atau tutor di Sekolah Indonesia Den Haag (SIDH) memberikan pengetahuan mengenai perbedaan sikap baik dan buruk, yang mana sikap toleransi merupakan salah satu dari bentuk sikap baik yang sangat penting. Tujuan pada tahapan ini yaitu agar siswa SIDH dapat memilah serta memilih terkait sikap-sikap baik yang perlu ada dalam dirinya, yang diantaranya yaitu sikap toleransi.

Selain itu, pada tahapan informasi ini juga sudah tertera jelas pada visi Sekolah Indonesia Den Haag (SIDH) yang termuat pada buku Pedoman Pengelolaan Layanan Pembelajaran Jarak Jauh SD, SMP dan SMA Sekolah Indonesia Den Haag Tahun Pelajaran 2017/2018 yaitu "Indonesian Values, International Standards". Melihat dari visi SIDH yang menggambarkan nilai moral Indonesia dengan standar internasional, maka hal ini sejalan dengan sikap toleransi yang juga perlu tumbuh dalam rakyat Indonesia baik di dalam negaranya sendiri maupun di luar negeranya. Nilai toleransi ini sudah dikembankan di Indonesia sebagai bentuk penghormatan terhadap multikulturalise Indonesia, baik dari segi suku, agama, ras dan Budaya..

b. Tahapan Penghayatan (ranah kognitif) 
Pada tahapan penghayatan ini, guru (tutor) memberikan arahan, bimbingan dan bentuk keteladanan kepada siswa-soswa di SIDH terkait penghayatan nilai Ilahiyah dan nilai Insaniyah (kaitan hubungan antara Allah swt dan hubungan sesama manusia). Penghayatan nilai-nilai Ilahiyah dan Insaniyah di SIDH yang telah diterapkan disana sejalan dengan proses internalisasi dalam tahap pelaksanaan yang dilakukan oleh Sholihin Tri Bagaskara di SMAN 1 Kraksaan Probolinggo, yaitu dalam tahap pelaksanaan internalisasi meliputi kegiatan pembelajaran, kegiatan keagamaan. (Sholihin Tri Bagaskara, 2017: 162)

Pada kegiatan pembelajaran yang berlangsung di SIDH, internalisasi sikap toleransi mendapat perhatian khusus di pembelajaran PAI. Pembelajaran PAI yang dilaksanakna di SIDh sendiri mendapat jam sebanyak 2 jam per minggu. Dalam waktu yang relatif singkat tersebut, maka proses internalisasi sikap toleransi di sana juga ditambah dengan di luar jam pelajaran, seperti pada kegiatan keagamaan yang meliputi pembiasaan sholat Jum'at bersama, pembiasaan tadarus al-Qur'an dan peringatan hari besar Islam.

\section{c. Tahapan Aplikasi (ranah psikomotorik)}

Selanjutnya, pada tahapan yang terakhir yaitu tahap pengaplikasian atau yang biasa disebut dengan implementasi sikap toleransi tersbut dalam penerapan kebijakan ataupun peraturan yang telah diterapkan di Sekolah Indonesia Den Haag. Selain diartikan sebagai wujud implementasi dalam kebijakan, tahap apliaksi ini juga disebut dengan pemberian motivasi dan dorongan kepada siswa SIDH, sehingga siswa tersebut dapat menerpakn sikap tolernasi dalam perbuatan dan kebiasaan seharihari. Kemudian, pengartian tahap aplikasi selanjutnya yaitu pemberian contoh atau teladan dan penciptaan suasana saling menghormati di lingkungan SIDH.

Berdasarkan tahapan aplikasi yang terjadi di SIDH, hal ini sejalan dengan peenrapan yang dilakukan di penelitian Imam Baihaqi di SMA Laboratorium Universitas Negeri Malang yang menyebutkan bahwa dalam tahap aplikasi sikap toleransi yang menonjol yaitu saling menghargai antar sesama saat terjadi peringatan hari raya masing-masing agama. Sehingga, internalisasi sikap toleransi dapat terwujud sesuai yang diharapkan. (Imam Baihaqi, 2019: 83) 


\section{Simpulan}

Internalisasi sikap toleransi perlu adanya pembinaan terkait menghargai pendapat mengenai pendapat orang lain yang berbeda dengan pemikiran sendiri serta saling tolong-menolong antar sesama manusia tanpa memandang suku, ras, dan agama. Dalam suatu pendidikan sikap toleransi sangat dibutuhkan agar tidak terjadi suatu masalah dalam lingkungan pendidikan maupun diluar pendidikan. Untuk memperdalam sikap toleransi dilakukan melalui proses pembinaan dan pemahaman tentang sikap toleransi yang sesuai dengan ajaran syariat Islam dan berpedoman dengan al-Quran dan Hadits. Dalam pendidikan memerlukan sebuah cara untuk dapat melakukan internalisasi sikap toleransi dengan mudah diterima dan memberikan hasil yang optimal. Cara-cara tersebut dalam pendidikan biasanya disebut dengan metode. Adapun metodenya yaitu teladan, arahan atau bimbingan, kontinuitas (pengulangan) dan pembiasaan dan petunjuk al-Quran dan Hadits. Dalam menjalankan suatu proses nilai internalisasi sikap toleransi melalui PAI harus melewati beberapa tahapan antara lain: tahapan informasi (ranah afektif), tahapan penghayatan (ranah kognitif), dan tahapan aplikasi (ranah psikomotorik).

Pada penelitian ini, internalisasi di SIDH dilakukan dengan metode teladan, bimbingan, dan pembiasaan melalui kegiatan pembelajaran Pendidikan agama Islam dan kegiatan penunjang Pendidikan agama Islam seperti sholat berjama'ah, berdo'a Bersama, dan Ramadhan camp. Sehingga disarankan pada penelitian selanjutnya dapat memberikan data terkait metode yang lainnya seperti dorongan atau motivasi dan pengorganisasian, dengan harapan dapat melengkapi dari semua metode internalisasi sikap toleransi yang digunakan dalam pembelajaran PAI di SIDH. 


\section{DAFTAR PUSTAKA}

Ainiyah, Nur. "Pembentukan Karakter Melalui Pendidikan Agama Islam": Jurnal Al-Ulum, Vol. 13 No. 1 Juni 2013.

Ali, Hery Noer. 1999. Ilmu Pendidikan Islam, Cet. Ke 1. Jakarta: Logos Wacana Ilmu.

Ardianto. "Internalisasi Nilai Karakter dalam Pembelajaran PAI melalui Keteladanan Pendidik": Jurnal Attaqwa, Vol.16 No. 1 Maret 2020.

at-Tawanisi, Abd Futuh dan al-Jumbulati, Ali. 1994. Perbandingan Pendidikan Islam, terj. M. Arifin, judul asli Dirasah Muqaranah fi al-Tarbiyah al-Islamiyah. Jakarta: Rineka Cipta.

Bagaskara, Sholihin Tri. 2017. "Internalisasi Nilai-Nilai Pendidikan Agama Islam Berbasis Toleransi Antar Umat Beragama di SMAN 1 Kraksaan Kabupaten Probolinggo", Skripsi UIN Maulana Malik Ibrahim Malang.

Baihaqi, Imam. 2019. "Internalisasi Sikap Toleransi melalui Pembelajaran Pendidikan Agama Islam di Sekolah Menegah Atas Laboratorium Universitas Negeri Malang”, Skripsi UIN Maulana Malik Ibrahim Malang.

Budiman, Ahmad. 2020. "Internalisasi Nilai-Nilai Agama di Sekolah dalam Menumbuhkan Moderasi Beragama (Studi Kasus SMAN 6 Kota Tangerang Selatan, Banten, Indonesia)", Tesis UIN Syarif Hidayatullah Jakarta.

Departemen Pendidikan Nasional, Standar Kompetensi Pendidikan Agama Islam, Jakarta: Depdiknas, 2003.

Fitri, Anggi. "Pendidikan Karakter Perspektif al-Qur'an dan Hadits": Jurnal Ta'lim, Vol. 1 No. 2 Juli 2018.

Habi, Abdul. "Budaya Toleransi Antar Umat Beragama dalm Pembelajaran Pendidikan Agama Islam di SMAN 1 Kempo Kabupaten Dompu": Jurnal Turatsuna, Vol. 2 No. 2 Agustus 2020.

Hamid, Abdul. 2016. "Metode Internalisasi Nilai-Nilai Akhlak Dalam Pembelajaran Pendidikan Agama Islam di SMP Negeri 17 Kota Palu: Jurnal Pendidikan Agama Islam-Ta'lim, Vol 14 No. 22016

Idris, Tasnim, Darmiah dan Fakhrul Rijal. "Internalisasi Nilai-Nilai Multikulturalisme dalam Pembelajaran PAI di Sekolah": Jurnal Cendekia, Vol. 17 No. 1 Juni 2019. 
KBBI Daring Kemendikbud. 2020. https://kbbi.kemendikbud.go.id/. Koesoema, Doeni, 2010. Pendidikan Karakter: Strategi Mendidik Anak di Zaman Global, Jakarta: Grasindo.

Masganti, Siti. 2010. "Optimalisasi Kompetensi Moral Anak Usia Dini": Jurnal Pendidikan dan Kebudayaan, Vol. 16 No. 1 Januari 2010.

Muliadi, Erlan. 2012. "Urgensi Pembelajaran Pendidikan Agama Islam Berbasis Multikultural Di Sekolah": Jurnal Pendidikan Islam, Vol. 1 No. 1 Juni 2012

Mumin, U. Abdullah. "Pendidikan Toleransi Perspektif Pendidikan Agama Islam (Telaah Muatan Pendekatan Pembelajaran di Sekolah)": Jurnal Al-Afkar, Vol. 2 No. 1 Juli 2018.

Munif, Muhammad. "Strategi Internalisasi Nilai-Nilai PAI dalam Membentuk Karakter Siswa": Jurnal Edureligia, Vol. 1 No. 1 Juni 2017.

Nurchaili, "Membentuk karakter Siswa Melalui Keteladanan Guru" dalam Jurnal Pendidikan dan Kebudayaan, Vol. 16 Edisi Khusus III Oktober 2010.

Nurliah. 2019. "Internalisasi Nilai-Nilai Pendidikan Agama Islam Berbasis Toleransi Antar Umat Beragama di SMKN 9 Pinrang”, Skripsi IAIN Parepare.

Profil Sekolah Indonesia Den Haag, http://www.sekolahindonesia.nl/profil-sekolah/, diakses pada 29 Januari 2021

Sani, Firly Maulana. 2016. "Nilai-Nilai Pendidikan Karakter dalam al-Quran Surat al-Baqarah ayat 261-267”, Skripsi UIN Walisongo Semarang.

Sari, Nedia Marpita. 2019. "Pola Internalisasi Nilai-Nilai Toleransi berbasis Multikultural alam Pembelajaran Pendidikan Agama Islam di SMPN 21 Kota Bengkulu", Skripsi IAIN Bengkulu.

Tim. 2017. Pedoman Pengelolaan Layanan Pendidikan Jarak Jauh SD, SMP dan SMA Sekolah Indonesia Den Haag Tahun Pelajaran 2017/2018. Belanda: Sekolah Indonesia Den Haag.

Ulwan, Nashih. 1993. Tarbaiyatu al-Aulad fi al-Islam, terj. Saifullah Kamalie dan Hery Noer Ali. Semarang: As-Syifa'.

Umroh, Afidatul. 2015. "Peran Guru Pendidikan Agama Islam Dalam Menginternalisasikan Nilai-Nilai Pendidikan Islam Untuk Menumbuhkan Sikap Toleran Antar Umat Beragama Siswa 
210 Riza, Nailna, Ahsan dan Huda, Internalisasi Sikap,...

Kelas XI SMK N 5 Yogyakarta," Skripsi UIN Sunan Kalijaga Yogyakarta.

Usman, Muhammad dan Anton Widyanto. "Internalisasi Nilai-Nilai Toleransi dalam Pembelajaran Pendidikan Agama Islam di SMA Negeri 1 Lhokseumawe, Aceh, Indonesia": Jurnal Dayah, Vol. 2 No. 1 Agustus 2019. 